\title{
AIR TEMPERATURE CHARACTERISTICS OF THE POSTOJNA AND PREDJAMA CAVE SYSTEMS
}

\section{ZNAČILNOSTI TEMPERATURE ZRAKA V POSTOJNSKEM IN PREDJAMSKEM JAMSKEM SISTEMU}

Stanka Šebela, Janez Turk

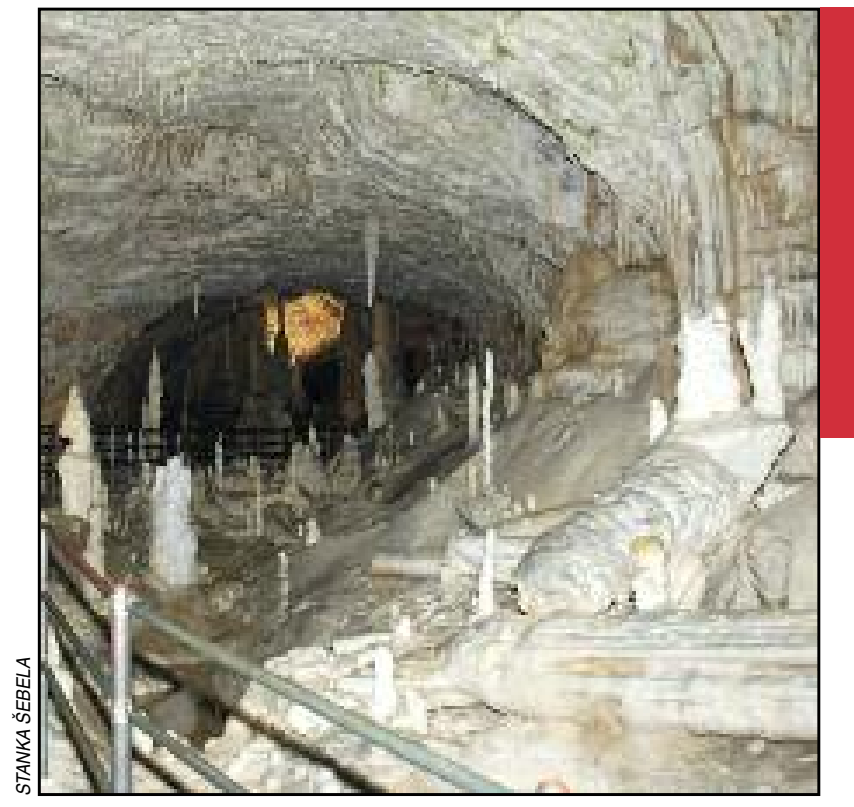

Lepe jame in the Postojna cave system.

Lepe jame v Postojnskem jamskem sistemu. 


\title{
Air temperature characteristics of the Postojna and Predjama cave systems
}

\author{
DOI: $10.3986 / A G S 51102$ \\ UDC: $911.2: 551.524(497.471)$ \\ 551.524:551.435.84(497.471)
}

COBISS: 1.01

\begin{abstract}
Monitoring of air temperature takes place at five locations in two cave systems. At monitoring location Velika gora (Postojna 1), mean air temperature for the time period $2009-2010$ was $11.10^{\circ} \mathrm{C}$. Of three monitoring locations Velika gora is situated at the highest absolute height. Mean air temperature in the same period was $10.66^{\circ} \mathrm{C}$ in the central part of the Lepe jame cave (Postojna 3 ) and $10.30{ }^{\circ} \mathrm{C}$ in the side passage (Postojna 2). Temperature difference between outside and cave temperature is the highest at Postojna 2 monitoring location, due to the inflow of the air currents from the unknown parts, especially in winter time. Manual temperature measurements (2004-2010) exhibit slight increase of air temperature at Postojna 1 and Postojna 2 monitoring sites. In the Predjama cave system, the air temperature in Velika dvorana is much more stable than in Konjski hlev passage, which is more subject to external influences.
\end{abstract}

KEY WORDS: geography, karstology, cave climate, monitoring of cave climate, air temperature, Postojna cave system, Predjama cave system, Slovenia

The article was submitted for publication on January 28, 2011.

\section{ADDRESSES:}

Stanka Šebela, Ph. D.

Karst Research Institute

Scientific Research Center of the Slovenian Academy of Sciences and Arts

Titov trg 2, SI - 6230 Postojna, Slovenia

E-mail: sebela@zrc-sazu.si

Janez Turk, Ph. D.

Lunačkova 4, SI - 1000 Ljubljana, Slovenia

E-mail: janez.turk@zrc-sazu.si

\section{Contents}

1 Introduction 45

$1.1 \quad$ Description of monitoring locations 47

1.2 Methodology 48

2 Results and discussion $\quad 49$

2.1 Postojnska jama system 49

2.2 Predjama cave system 53

3 Conclusion 56

4 References $\quad 56$ 


\section{Introduction}

Postojnska (20,570 m) and Predjama (13,092 m) cave systems are two of the longest and most visited karst caves in Slovenia. In the frame of the projects Expert control and recommendation for management of cave systems: climatic and biologic monitoring of cave systems (financed by the Postojnska jama d.d.) and Measurements and analysis of selected climatic parameters in karst caves: example of the Postojna cave system (co-financer is Slovenian Research Agency) regular monitoring of cave climate has been going on since 2009. Monitoring takes place at certain micro-locations in two caves. However, continuous monitoring of air temperature in Postojna cave system (Postojna 2, figure 1) had already started in 2008.

Basic statistics of the air temperature from the two cave systems are presented in the paper. Statistics are based on one year's data. The main characteristics of cave climate are interpreted, based on measurements that were performed either at one hour or ten minute intervals. Manual measurements of air temperature are presented as well for the Postojna cave system. Those measurements have taken place since 2004.

Postojna cave system is a complex climatic system, due to the great length of the passages, large entrances that are situated at different altitudes, the ponor of the Pivka River and also due to the great variations in external temperature and amount of participation throughout the year. During winter time, cool air penetrates to the cave through main entrances. Air warms in the cave, for this reason it becomes less dense and it flows to the surface through the higher entrances or through numerous fissures. Air circulation is just the reverse during summer time. Cooler air flows out of the Postojna cave system through the lower entrances (Gabrovšek and Mihevc 2009).

A comprehensive meteorological study of Postojna cave system was carried out by Crestani and Anelli (1939). They measured air temperature, temperature of underground Pivka River, temperature of bedrock and direction of wind. Moreover, they measured also air pressure and relative humidity. Directions of air circulation during winter and summer regimes are shown on cross-profiles (for example in Veliki dom chamber, Otoška jama cave and Pivka jama cave). Also the influence of frost action in the cave (mainly in the entrance part of the cave) and meteorological conditions of breathing-holes on the surface above the cave were studied.

When air that flows into the cave cools, then it becomes denser and it moves to the lower part of the cave. When it warms in the cave, it moves to the upper part of the cave. Such caves are called dynamic caves (Gams 2004). Intensity of mixing between cave air and fresh air coming from the outside depends on several factors. One of them is the ratio between size of the cave entrance and cave depth, another factor is variation of air pressure. When the air pressure increases, air flows to the cave. When a depression is approaching, air flows out from the cave. Variations of water table have important influence on air movement in water caves (Gams 2004).

The system of the Postojna cave is composed of variable sections, from the meteorological point of view. Dynamic sections (regarding air circulation) are mainly passages Spodnji Tartar, Rov brez imena, Lepe jame, while Biospeleološka postaja and Pisani rov passage are more static (Gams 1970).

Transition from one to another regime (typical for winter or summer) can occur between a warm noon and cool night. Air circulation can be very limited in the spring and autumn, when temperature differences between the cave and outside are low. However, there are also exceptions. When partisans caused the explosion of the oil stored in the entrance parts of Postojna cave in spring of 1944 the wind was blowing to the cave and smoke left soot all along to the Kongresna dvorana chamber (Gams 2004).

Also the Predjama cave system represents an interesting place to study cave meteorology, due to the entangled geometry of the passages and several entrances that are situated at different altitudes. Anelli (1941-1944) represented results of meteorological observations in that system. He observed air circulation and measured air temperature. He described the principle of air trap, which is characteristic for Konjski hlev passage. There are two air flows of different temperatures while one enters the cave the other leaves the cave. When air temperature was very low (for example in January 1943), warm cave air flowed to the surface from the Fiženca passage. For this reason, cloud formed at the entrance to the Fiženca (Anelli 1941-1944).

Habe (1970) represented cave temperature data for passages Lokva, Stara jama, Fiženca, Blatni rov, Velika dvorana chamber, Črna dvorana chamber and Vzhodni rov passage, all in the Predjama cave system. Data were collected from February 1956 to February 1957. Moreover, he measured also wind, humidity, and temperature of bedrock. Habe (1970) described summer and winter regime and also a transitional period, when two regimes alter from one to another. In summer regime, air flows from the Zahodni rov 


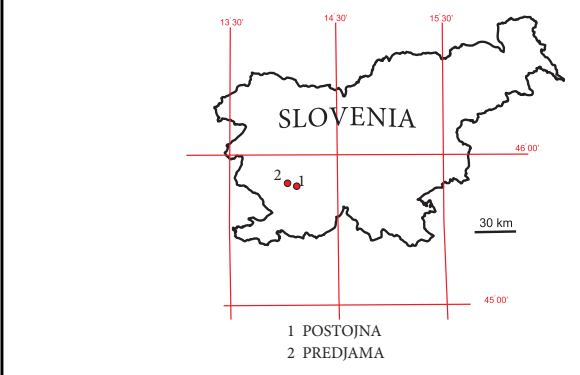

करत

Zahodni roy
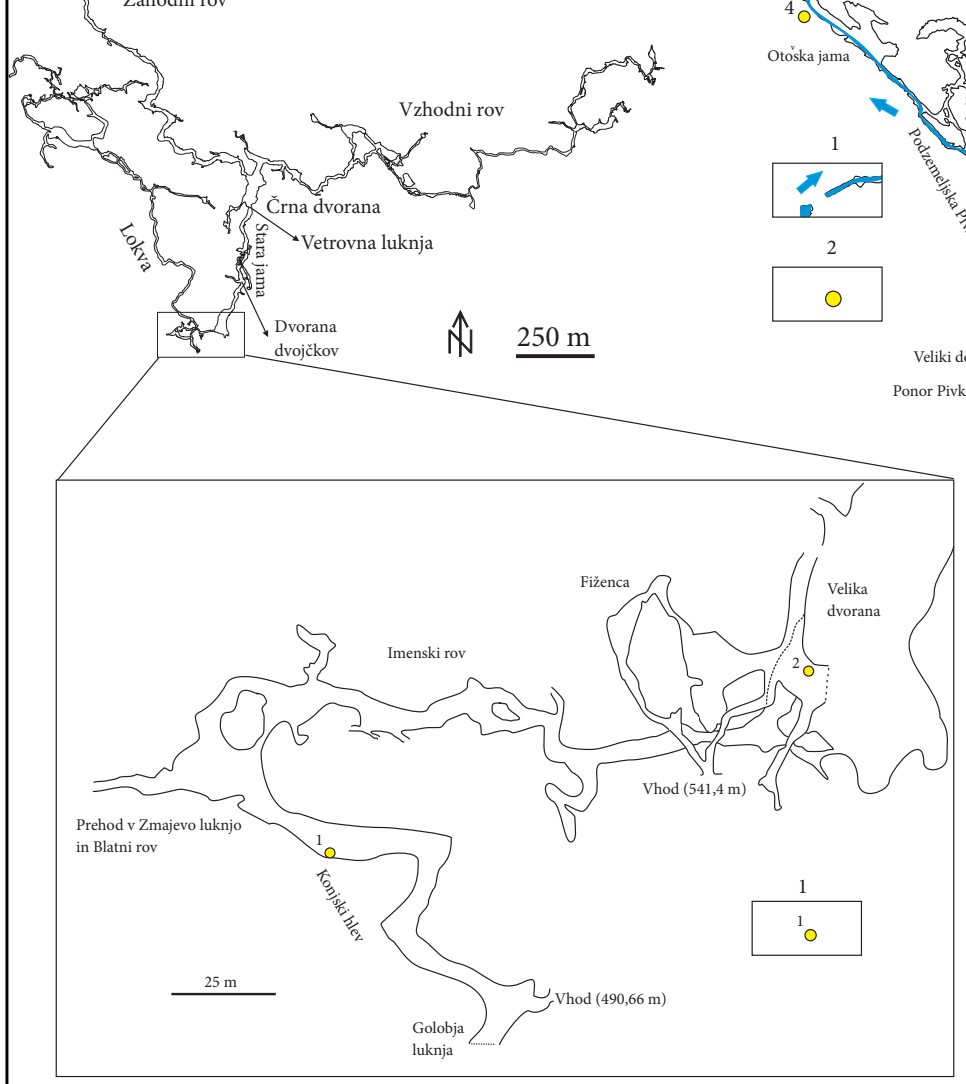

1.
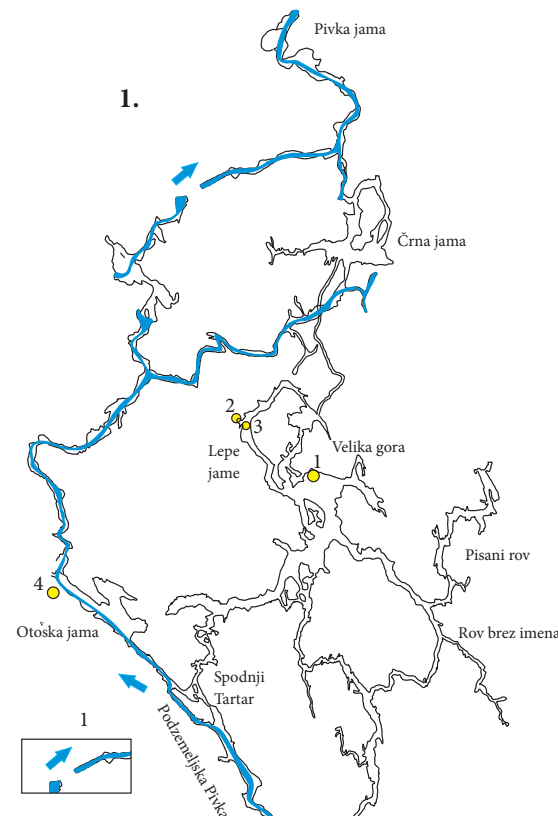

* Spodnji
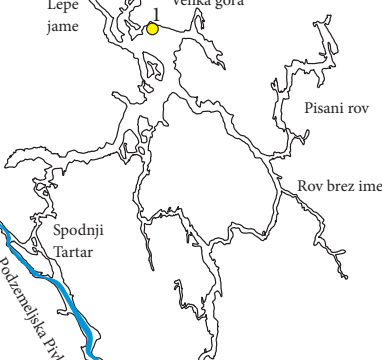

$\hat{N}$ 
passage and the Vzhodni rov passage through the Vetrovna Luknja passage to the Velika dvorana, where another cooler air flowing from Fiženca joins. Cooler cave air leaves the cave from all openings of Lokva passage and Zmajeva luknja passage. Air penetrates through Vetrovna luknja passage to Črna dvorana chamber in winter time. The highest velocity of wind in Vetrovna luknja was measured in February 1956; it was $8.3 \mathrm{~m} / \mathrm{s}$. When outside temperatures are very low, ice stalagmites occur all the way to Dvorana dvojčkov chamber (Habe 1970).

Kranjc (1983) described the influence of frost action on deposition of flowstone in the entrance parts of Predjama cave system. Most flowstone falls off due to the frost action in late autumn, while this process was less intensive in summer and early autumn. In the period $9^{\text {th }}$ January 1980 to $31^{\text {st }}$ March 1981 Kranjc (1983) measured air temperature and humidity in Golobja luknja chamber and in Vetrovna Luknja passage. The highest measured velocity of wind in Vetrovna luknja was $9 \mathrm{~m} / \mathrm{s}$ ( $9^{\text {th }}$ January 1981).

Each cave system has special climate peculiarities but some characteristics of cave temperature are common (Smithson 1991). It is valid also for Postojna and Predjama cave systems. Cave climate is of special interest in recent years and numerous surveys have been carried out (Badino 2010; Culver and Pipan 2010; Šebela and Turk 2011). Cave environment is subjected also to climate changes and natural hazards (Badino 2004; Komac 2009).

\subsection{Description of monitoring locations}

Common manual thermometers were placed at two locations, where cave air temperature was recorded occasionally during our visit. These two locations are Postojna 1 (air temperatures were read since $26^{\text {th }}$ May 2004) and Postojna 2 (air temperatures were read since $18^{\text {th }}$ May 2004). Automatic thermometers were installed later. Automatic monitoring of air temperature started on $21^{\text {st }}$ July 2008 at monitoring location Postojna 2 in Lepe jame (figure 1). Monitoring was later established also at locations Postojna 1 (1 $8^{\text {th }}$ March 2009) and Postojna 3 ( $6^{\text {th }}$ May 2009). Monitoring location Postojna 1 (Velika gora) is $561.4 \mathrm{~m}$ above sea level, on the top of this collapse chamber (figure 2). Thermometer is $0.2 \mathrm{~m}$ above the floor and $0.1 \mathrm{~m}$ far from a collapsed block. There is a $65 \mathrm{~m}$ thick limestone roof above the chamber (Šebela 2010). Postojna 2 is situated in an artificially enlarged side passage in Lepe jame. It is $526 \mathrm{~m}$ above sea level and

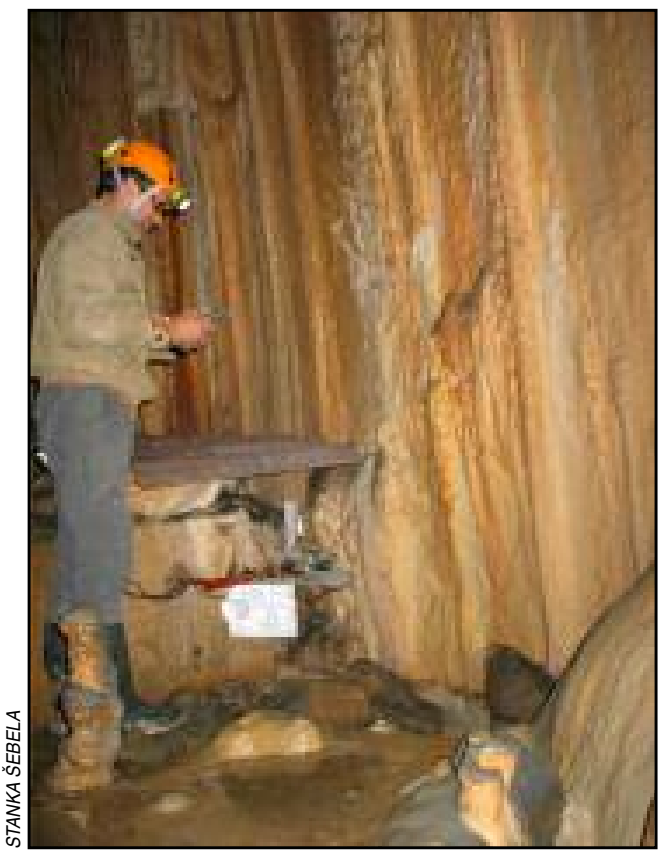

Figure 2: Monitoring of air temperature at Velika gora chamber (Postojna 1). 


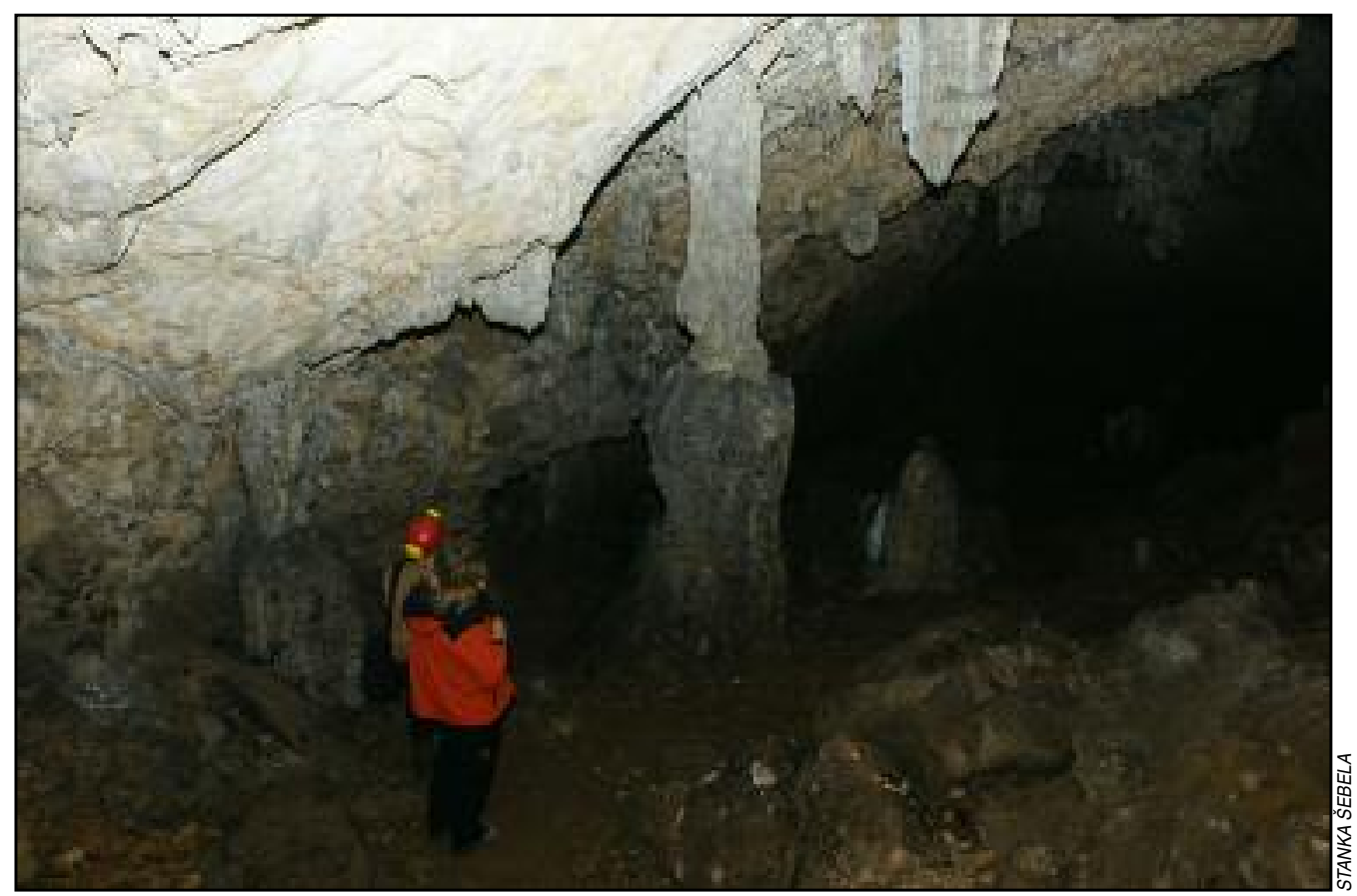

Figure 3: Monitoring of air temperature at Velika dvorana chamber (Predjama cave system).

there is a $58 \mathrm{~m}$ thick limestone roof above it. Thermometer was installed $0.3 \mathrm{~m}$ above the floor and $0.3 \mathrm{~m}$ far from cave wall. The third monitoring location (Postojna 3 ) is situated in the middle of the Lepe jame passage. It is $524 \mathrm{~m}$ high (a.s. 1.) and it is $12 \mathrm{~m}$ away from the monitoring location Postojna 2 (figure 1). Thermometer at Postojna 3 location is $0.1 \mathrm{~m}$ distant from flowstone and is $0.2 \mathrm{~m}$ above the floor.

Monitoring of the air temperature started on $6^{\text {th }}$ May 2009 in Predjama cave system. Two monitoring locations were established in the cave. First monitoring location is situated in the entrance part of the cave, i.e. in Konjski hlev passage at $488 \mathrm{~m}$ above the sea level. Second monitoring location is situated in Velika dvorana chamber $(492.5 \mathrm{~m}$ ) (figures 1 and 3 ). Thermometer is installed $0.3 \mathrm{~m}$ above the floor and $0.05 \mathrm{~m}$ far from wall in Konski hlev passage monitoring location. Thermometer is $0.3 \mathrm{~m}$ above floor in Velika dvorana, distance from a collapsed block is $0.05 \mathrm{~m}$.

There are three monitoring locations to measure air temperature in the Postojna cave system, and two in Predjama. On $7^{\text {th }}$ October 2009, a monitoring location was established also at the surface outside the cave. A thermometer was placed in the forest near entrance to Otoška jama cave at $545 \mathrm{~m}$ above sea level (figure 1).

\subsection{Methodology}

Air temperature was measured with thermometers called divers, produced by Van Essen. Temperature accuracy is $\pm 0.1^{\circ} \mathrm{C}$. Measurements in Postojna cave system did not take place always continuously, due to the technical problems. Air measurements took place every hour, in some periods also every 15 minutes or even every 2 minutes.

Measurements were continuous all the time in Predjama cave system. Measurements took place every 10 minutes at both locations in Predjama cave system.

Air temperature data are shown on graphs (figures 4, 5, 6, 7 and 8). Also temperature data for outside are shown, in order to enable comparison between cave and outside temperature. Beside outside temperatures that were measured in the forest above Otoška jama cave, additional temperature data for Postojna were 
obtained from Environmental Agency of Slovenian Ministry for environment and spatial planning. We believe that air temperatures at Predjama and above the Otoška jama cave do not differ significantly, due to the similar topographic and vegetation characteristics of two locations. Distance between these two locations is around $9 \mathrm{~km}$. For this reason, air temperature was measured only above Otoška jama and applied to compare outside temperatures with cave temperatures in Predjama.

Continuous set of one year long measurements (12 ${ }^{\text {th }}$ August $2009-12^{\text {th }}$ August 2010 for Postojna cave system and $6^{\text {th }}$ August $2009-6^{\text {th }}$ August 2010 for the Predjama cave system) was analyzed by basic statistics. Maximal, minimal and mean air temperatures were determined for each of monitoring locations.

Data based on manual measurements of air temperature (monitoring locations Postojna 1 and Postojna 2) since 2004 are shown on the graph that exhibits also a temperature trend (figure 6). Also basic statistics were carried out. Air temperature data were manually recorded at least once per month.

\section{Results and discussion}

\subsection{Postojna cave system}

Air temperature that was monitored at three locations in Postojna cave system was statistically analyzed for a period of one year (12.8.2009-12.8.2010). Set of data at all three locations was analyzed (table 1).

Air temperature is the highest at Velika gora chamber (Postojna 1) monitoring site; mean annual temperature is $11.10^{\circ} \mathrm{C}$ (table 1 ). Temperature is relatively stable there, annual variations range for $0.5^{\circ} \mathrm{C}$ only. Air temperature at Velika gora exhibits characteristic seasonal trend. During the autumn and winter, air gradually cools in this part of the cave, while gradual warming can be observed in spring and summer. Air temperature reaches its annual maximum approximately at the end of September, while temperature minimum is reached at the end of March (figure 4).

Table 1: Basic statistics of air temperature in the Postojna cave system (12.8.2009-12. 8. 2010).

\begin{tabular}{lcccc}
\hline & $\begin{array}{c}\text { Postojna 1- } \\
\text { Velika gora }\left({ }^{\circ} \mathrm{C}\right)\end{array}$ & $\begin{array}{c}\text { Postojna 2- } \\
\text { Lepe jame }\left({ }^{\circ} \mathrm{C}\right)\end{array}$ & $\begin{array}{c}\text { Postojna 3- } \\
\text { Lepe jame }\left({ }^{\circ} \mathrm{C}\right)\end{array}$ & $\begin{array}{c}\text { Surface above } \\
\text { Otoška jama }\left({ }^{\circ} \mathrm{C}\right)\end{array}$ \\
\hline Mean & 11.10 & 10.30 & 10.66 & 9.20 \\
Standard deviation & 0.12 & 0.27 & 0.09 & 8.74 \\
Number of measurements & 8749 & 8752 & 8745 & 8754 \\
Minimal value & 10.89 & 9.89 & 10.34 & -15.60 \\
Maximal value & 11.37 & 10.99 & 11.23 & 32.10 \\
\hline
\end{tabular}

A similar seasonal temperature trend can be observed also at the surface (data obtained in the monitoring location above Otoška jama (figure 4). However, seasonal temperature maximum and minimum measured in Velika gora occurred with some phase shift in comparison with seasonal maximum and minimum temperature at the surface. Mean monthly air temperature is usually highest in July (around $18^{\circ} \mathrm{C}$ ) in Postojna (at the surface). It is similar, but usually slightly lower in August. The coolest month is usually January (around $-1{ }^{\circ} \mathrm{C}$ ), December and February are usually slightly less cool. Seasonal temperature maximum and minimum in the Postojna cave (Velika Gora) are delayed for approximately two or three months in comparison with seasonal temperature maximum and minimum at the surface. However, temperature changes in the cave system are minor in comparison with temperature changes at the surface. Air temperature at Velika gora fluctuates slightly; it is around $11^{\circ} \mathrm{C}$, seasonal temperature maximum and minimum deviate only for a few tenth degrees Celsius. It means that the cave cools in period when outside temperature remains below $11^{\circ} \mathrm{C}$ and warms when outside temperature increases above $11^{\circ} \mathrm{C}$. Outside temperature does not stay above $11^{\circ} \mathrm{C}$ for a long period of time till end of winter (second half of March to April). When such temperature conditions remains for a few days, then relatively warm air penetrates also to deeper parts of the cave system. Reverse process takes place when seasonal maximum occurs in the cave. At the end of September, nights become cool enough (below $11^{\circ} \mathrm{C}$ ), consequently cool air flows to the cave during the night and later also during the day. For this reason seasonal trend inverts, cave air begins to cool gradually (Šebela and Turk 2011). 


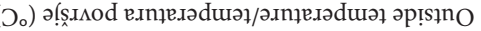

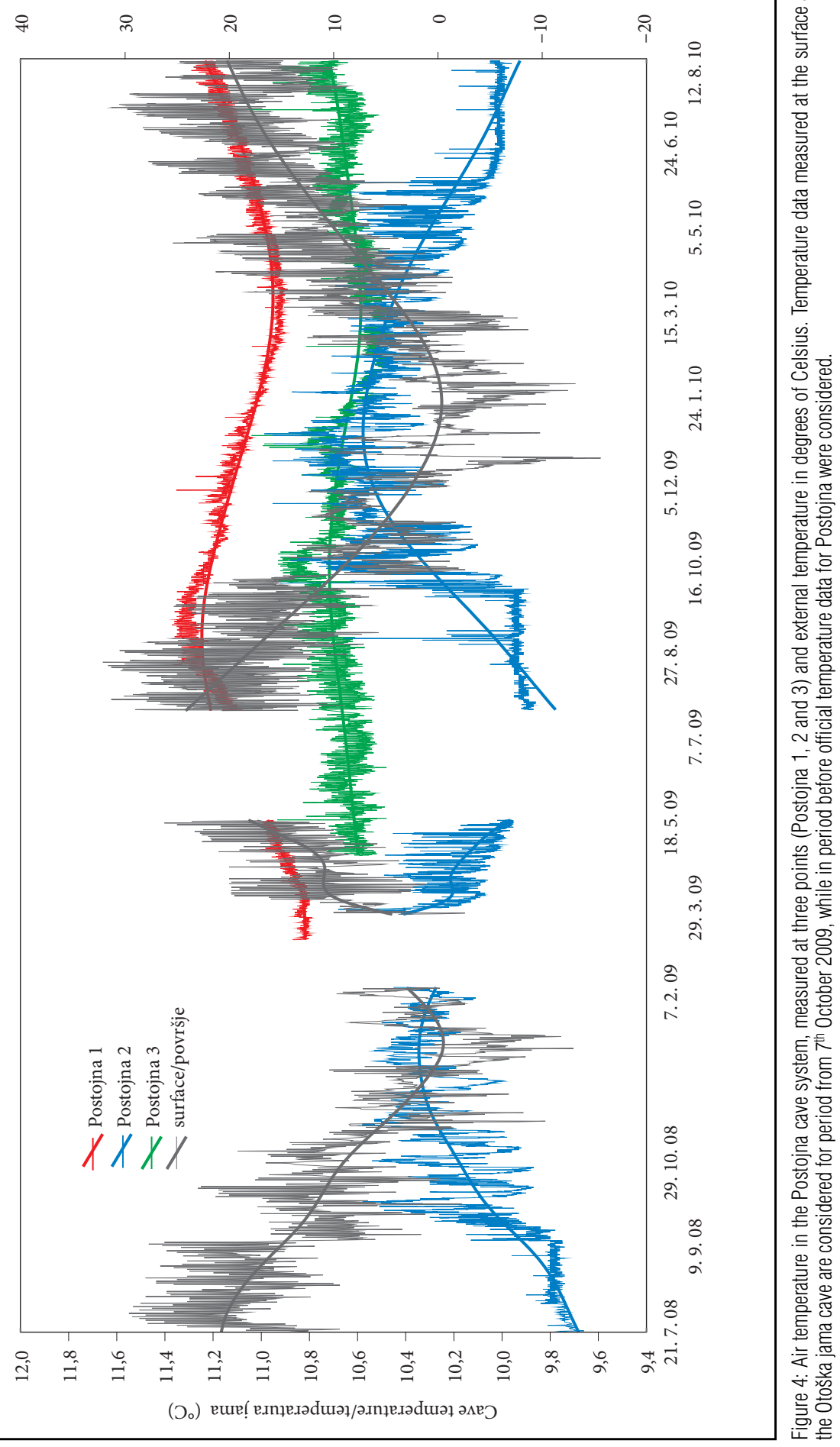




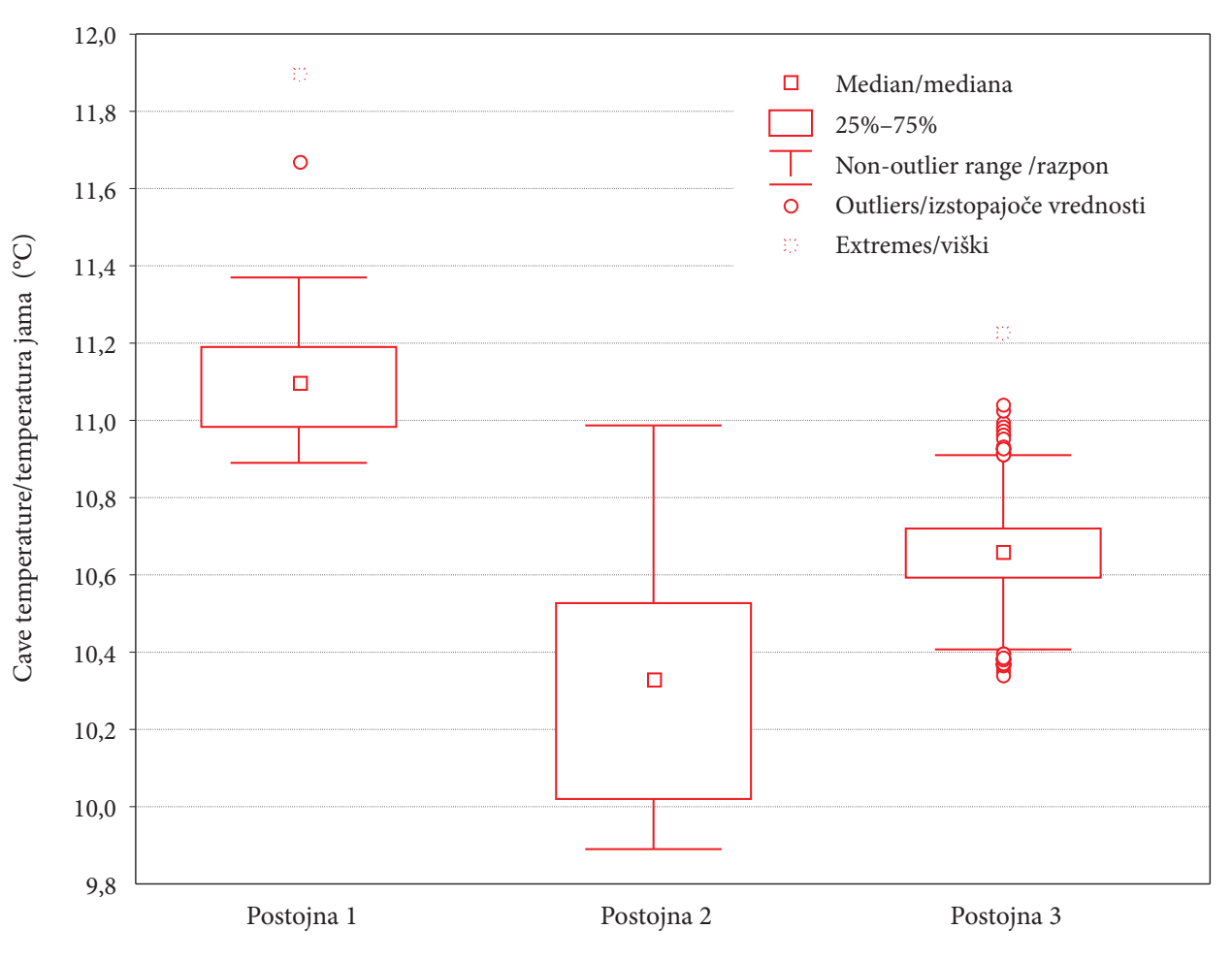

Figure 5: Fluctuations of air temperature (in degrees Celsius) for the Postojna cave system represented by box-whisker diagram. Quartiles and median are shown (Postojna 1, 2 and 3 ).

Air temperature at two other monitoring locations in Postojna cave system is significantly lower than at Velika gora (figures 4 and 5). Monitoring location at Velika gora (Postojna 1) is situated at the top of collapse chamber; it is 35-37 metres higher than Lepe jame (Postojna 2 in 3). Cave system is very dynamic regarding air circulation and for this reason air temperature is constantly higher just below the ceiling and at higher locations than at the floor of passages and at lower locations.

Air temperature measured at monitoring location Postojna 2 significantly differs from one measured at Velika gora (Postojna 1). Temperature at Postojna 2 is significantly lower (figure 5), moreover it exhibits no significant correlation with temperature at Velika gora (correlation coefficient is: $\mathrm{r}=-0.46$ ). Seasonal trend at Postojna 2 is just a reverse as expected (figure 4 ). Temperature is lowest during the summer. It is very stable in summer time, and remains around $9.9-10^{\circ} \mathrm{C}$. This is close to the minimal temperature observed at Postojna $2\left(9.89^{\circ} \mathrm{C}\right)$ (table 1$)$. Air temperature at Postojna 2 monitoring site is very variable during autumn, winter and spring, when outside temperature drops below cave temperature $10-11^{\circ} \mathrm{C}$ for a longer period or at least during the night. Temperature at Postojna 2 is significantly higher in such conditions than in summer time. In winter time, temperature is constantly higher than in summer at Postojna 2 site. Relatively high temperature variations (a few tenths to around half degrees Celsius) that occur at Postojna 2 in daytime (figure 4) can be attributed to changeable direction of circulation of local air masses (Šebela and Turk 2011). Air enters to the cave mainly through blowing-holes that occur in the ceiling of Lepe jame, according to Gams (1970).

According to the measurements, mean annual air temperature in Lepe jame (Postojna 3 ) is $10.66^{\circ} \mathrm{C}$. It is for $0.5^{\circ} \mathrm{C}$ lower than air temperature at Velika gora (table 1). Temperature data show that fluctuations are very similar both at Lepe jame (Postojna 3 ) and at Velika gora. Similar diurnal temperature variations occur at both locations (figure 4). However, seasonal trend at Lepe jame is less significant. 

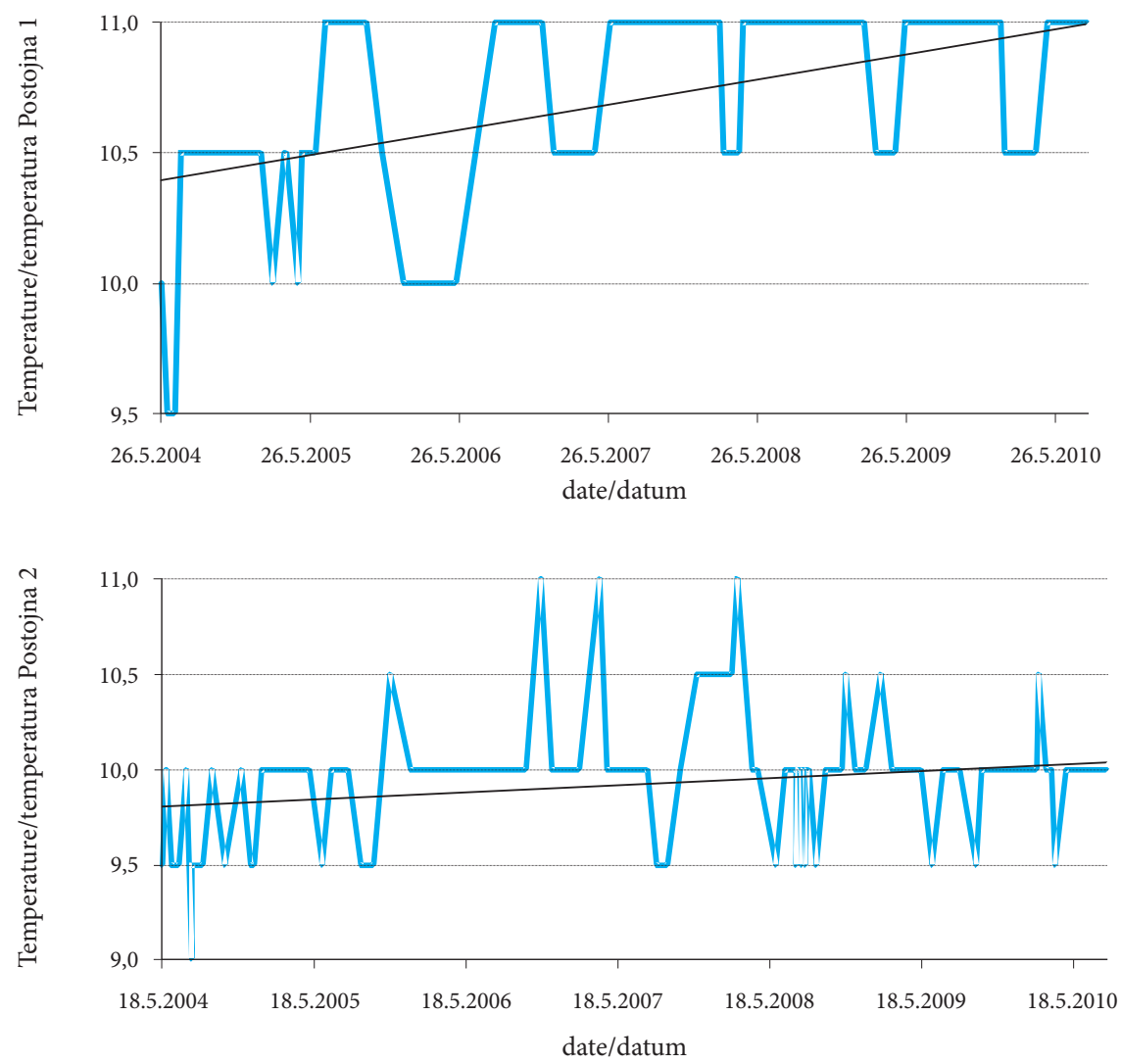

Temperature/temperatura _ _ Linear temperature/linearna temperatura

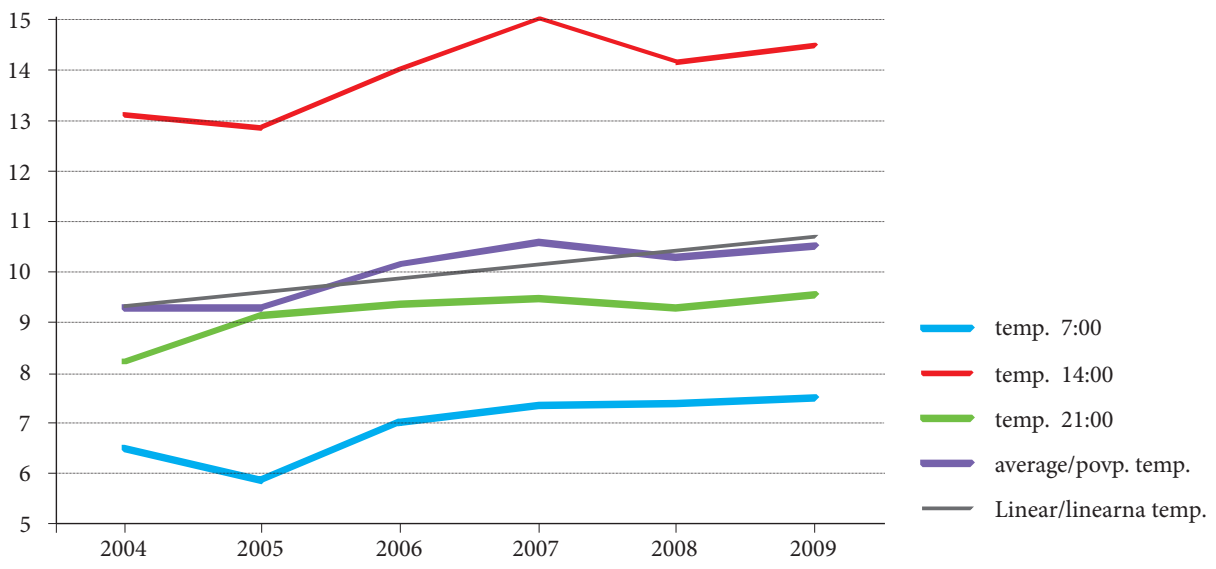

Figure 6: Air temperature in degrees Celsius (2004-2010) for the Postojna cave system, measured at two locations (Postojna 1 and 2) and mean annual temperature for external environment (Postojna meteorological station), based on temperature measurements at 7am, 2pm and 9pm (reference: ARSO). A - Postojna 1, B - Postojna 2, C - Postojna surface. 
Table 2: Basic statistics of air temperature in the Postojna cave system (2004-2009).

\begin{tabular}{lccccc}
\hline & $\begin{array}{c}\text { mean T }\left({ }^{\circ} \mathrm{C}\right) \\
2004-2010\end{array}$ & $\begin{array}{c}\text { mean T }\left({ }^{\circ} \mathrm{C}\right) \\
2009-2010\end{array}$ & $\begin{array}{c}\text { T difference } \\
\text { Postojna 1 } \\
\text { and 2 (2004-2010) }\end{array}$ & $\begin{array}{c}\text { T difference } \\
\text { Postojna 1 } \\
\text { and 2 (2009-2010) }\end{array}$ & $\begin{array}{c}\text { No. measurements } \\
\mathrm{N}\end{array}$ \\
\hline $\begin{array}{lccccc}\text { Postojna 1 } \\
\text { Postojna 2 }\end{array}$ & 10.73 & 11.09 & 0.81 & 0.77 & 115 \\
$\begin{array}{l}\text { Postojna } \\
\text { above Otoška } \\
\text { jama cave }\end{array}$ & 9.92 & 10.32 & 0.81 & 0.77 & 118 \\
\hline
\end{tabular}

*data for 2004-2009 (Internet 1)

Temperature data obtained by manual measurements at locations Postojna 1 and 2 are shown on the graph (figure 6). Slight increasing trend in temperature was observed at both locations in period 2004-2010. Mean air temperature at Postojna 1 was $10.73^{\circ} \mathrm{C}$ in period $26^{\text {th }}$ May 2004 to $12^{\text {th }}$ August 2010. Mean air temperature in the same period in Lepe jame (Postojna 2) was $9.92^{\circ} \mathrm{C}$ (table 2). Difference in air temperature at both sites (Postojna 1 and 2) measured manually is $0.80^{\circ} \mathrm{C}$, while difference between Postojna 1 and 2 measured by automatic thermometers was $0.77^{\circ} \mathrm{C}$ (table 2).

Also mean annual temperature for the surface (Postojna) exhibits slight increasing trend in the period 2004-2009 (Internet 1).

Cave temperature usually correlates well with external climate. Global climate changes can have influence also on underground (cave) climate (Badino 2004). However, long term measurements and statistical processing of long term data is required, to confirm such hypothesis.

According to some models, transfer of heat from the surface through the rock-bed towards the cave can take place for a long period. Lojen and Domínguez-Villar $(2010,33)$ made a model of such heat transfer to the Pisani rov passage of Postojna cave. This model showed that temperature signals need around 20 years to penetrate to the cave (Pisani rov). Based on this model, they think that temperature increases constantly in Pisani rov and that it will increase for one degree of Celsius till year 2030. However, our data indicate that also other factors should be taken into consideration, such as inflow of heat through main cave entrances by natural air circulation. This process is confirmed by occurrence of diurnal temperature variations in the cave.

\subsection{Predjama cave system}

Measurements of air temperature took place every 10 minutes in Predjama cave system in the period $6^{\text {th }}$ August 2009 to $6^{\text {th }}$ August 2010. This period is shown on figure 7 and in table 3.

Mean annual temperature in monitoring location at Konski hlev passage was $8.67^{\circ} \mathrm{C}$. Mean annual temperature at the surface near Postojna (above Otoška jama cave) was $9.25^{\circ} \mathrm{C}$ in the same period (table 3 ). Mean annual temperature in Konjski hlev is very similar to the mean temperature of Postojna (1960-1990), which is $8.4^{\circ} \mathrm{C}$ (internet 1). Mean annual air temperature in Velika dvorana chamber is surprisingly low. It is $6.80^{\circ} \mathrm{C}, 2.45^{\circ} \mathrm{C}$ lower than temperature measured at the surface above Otoška jama cave (table 3).

Table 3: Basic statistics of air temperature in the Predjama cave system (6 $6^{\text {th }}$ August 2009 to $6^{\text {th }}$ August 2010).

\begin{tabular}{lccc}
\hline & Konjski hlev $\left({ }^{\circ} \mathrm{C}\right)^{\star}$ & Velika dvorana $\left({ }^{\circ} \mathrm{C}\right)^{\star}$ & Surface $\left({ }^{\circ} \mathrm{C}\right)^{\star \star}$ \\
\hline Mean & 8.67 & 6.80 & 9.25 \\
Standard deviation & 4.00 & 2.18 & 8.79 \\
Number of measurements & 52,399 & 52,424 & 8756 \\
Minimal value & -0.35 & 0.81 & -15.61 \\
Maximal value & 18.67 & 10.25 & 32.10 \\
\hline
\end{tabular}

* 10 minute measuring interval

** 1 hour measuring interval 
(Јо) ว!ș.

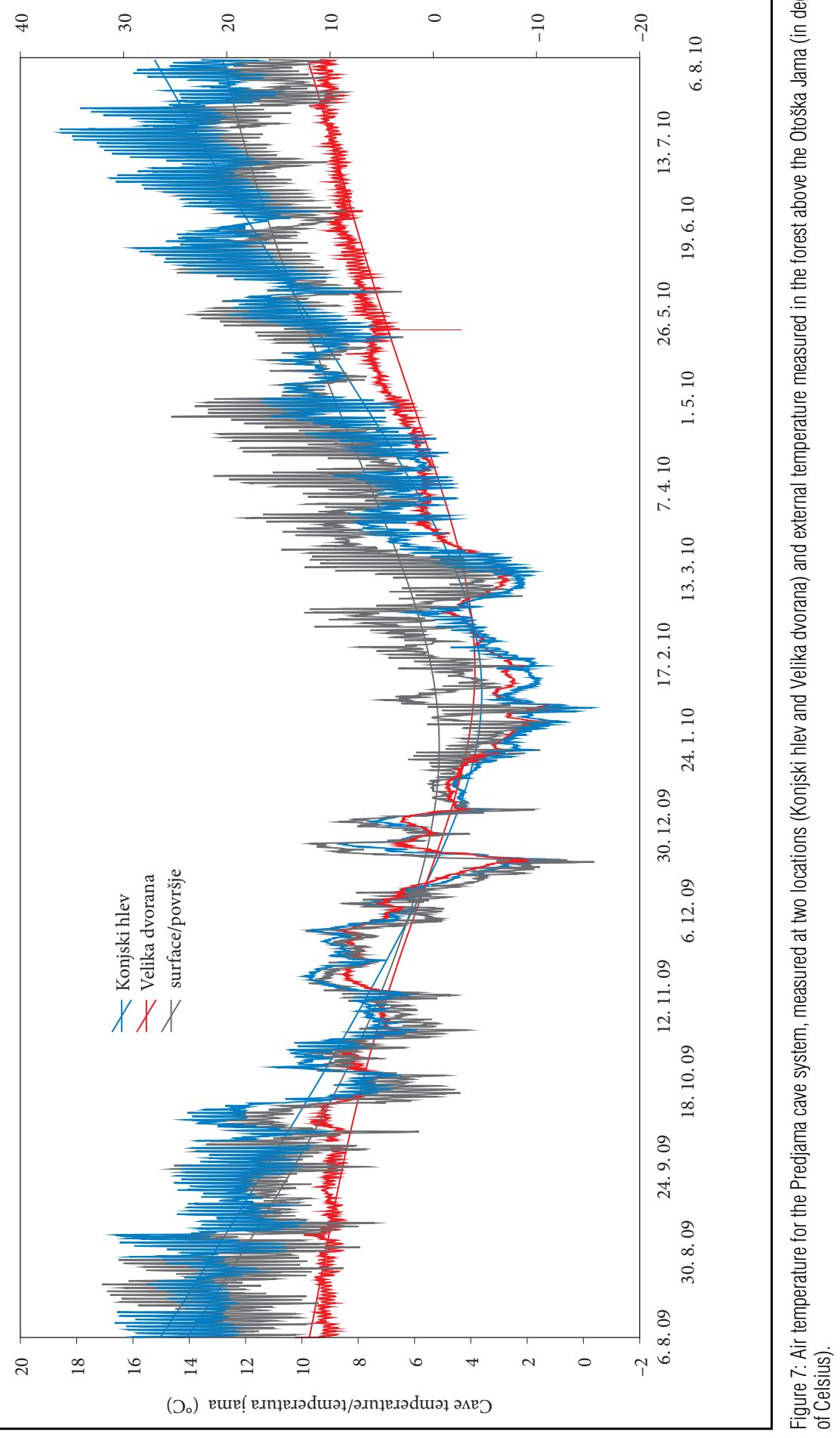




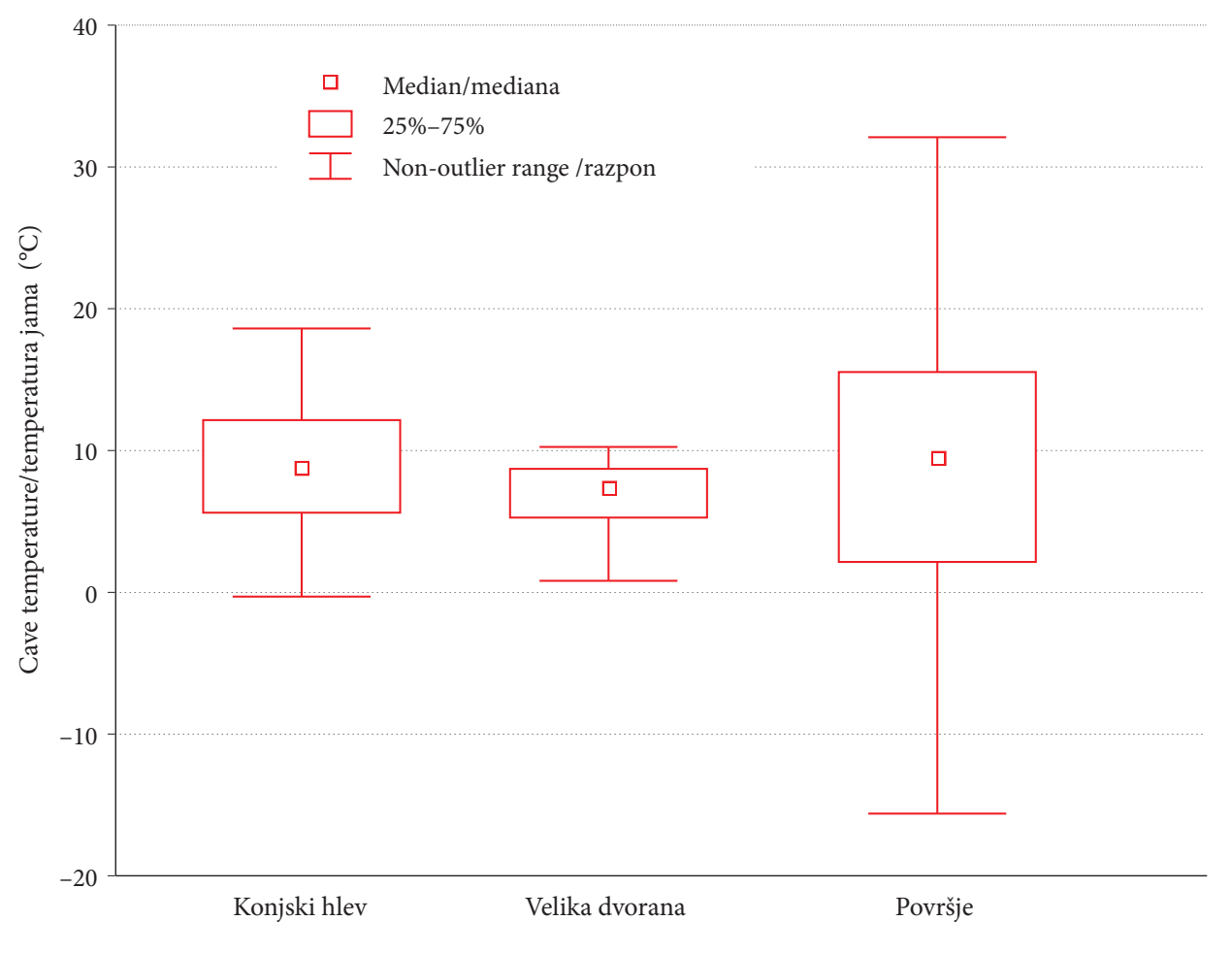

Figure 8: Fluctuations of air temperature (in degrees Celsius) for Konjski hlev and Velika dvorana in the Predjama cave system and for the surface (forest above the Otoška Jama - $9 \mathrm{~km}$ far from the Predjama), all represented by box-whisker diagrams. Quartiles and median are shown.

Air temperature in Konjski hlev passage exhibits the same seasonal trend as surface temperature. Monitoring location in Konjski hlev passage is close to the entrance. For this reason, the influence of external climate is very significant there.

According to the data, air temperature at monitoring location Konjski hlev passage fluctuates up to $18^{\circ} \mathrm{C}$ in its annual cycle. Annual data from period $6^{\text {th }}$ August 2009- $6^{\text {th }}$ August 2010 show that minimal temperature only slightly decreases below $0{ }^{\circ} \mathrm{C}$, while maximal temperature increases up to $18.67^{\circ} \mathrm{C}$ in the summer (table 3). Air temperature fluctuates also in the diurnal cycle; fluctuations are up to $6^{\circ} \mathrm{C}$ (figure 7 ). Such high diurnal temperature fluctuations are characteristic for the warmer part of the year, mainly for the summer.

Habe (1970) reported that local air flow occurs in Konjski hlev. Part of the air flows to the cave and out of the cave through the same channels, hence, the circulation is closed with 12 hours periodicity. Such air circulation can be explained by the influence of external temperatures in Konjski hlev, where diurnal temperature fluctuations are very significant. These fluctuations occur due to the temperature difference between the day and night.

The second monitoring location was in Velika dvorana passage (figure 3). External influences are lower in Velika dvorana than in Konjski hlev. Diurnal temperature fluctuations still occur in Velika dvorana but their amplitude is much lower than at Konjski hlev monitoring location (figure 7). Temperature fluctuates for almost $10.5^{\circ} \mathrm{C}$ in Velika dvorana, in annual cycle and for around $1^{\circ} \mathrm{C}$ or less in diurnal cycle (table 3).

In the warmer part of the year, air temperature in Velika dvorana fluctuates only in diurnal cycle. Other temperature changes that occur in external environment do not influence the cave temperature in Velika dvorana, until the air circulation in the cave changes. Air temperature in the warmer part of the monitoring period was around $9.5^{\circ} \mathrm{C}$ (figure 8 ). In the spring, as soon as external temperatures increase and 
remain above the mean annual temperature $\left(9-10^{\circ} \mathrm{C}\right)$, air begins to warm gradually in Velika dvorana. This process is gradual and it takes place till summer, when temperature in cave stabilizes at around $9-10^{\circ} \mathrm{C}$.

\section{Conclusion}

Postojna and especially Predjama caves are typical cave systems with numerous entrances situated at different absolute heights. Both systems are dynamic and have complicated climate characteristics. Influence of external climate can be detected also deep inside the cave. Winter and summer regime of air circulation can be observed in both cave systems.

Analysis of hourly air temperature data (12.8.2009-12.8.2010) collected from three monitoring locations in Postojna cave system revealed some interesting differences, but also similarities between three sites. Air temperature is generally the highest at Velika gora (Postojna 1) monitoring location, which is also situated at the highest absolute height. Mean annual air temperature at this location is $11.10^{\circ} \mathrm{C}$ (table 1 ). Temperature conditions are quite different in Lepe jame passage (Postojna 2), this monitoring location is situated $35 \mathrm{~m}$ lower than Velika Gora monitoring location. Mean annual temperature at Postojna 2 monitoring location is $10.30^{\circ} \mathrm{C}$. Seasonal trend of air temperature is just the reverse here in comparison with the trend at Velika gora, which is in good accordance with outside seasonal trend. Air gradually cools during autumn and winter time at Velika gora. While gradual warming occurs in spring and summer (figure 4). Monitoring location Postojna 2 is situated in an artificially enlarged passage with dimensions $7 \times 1 \times 1.5 \mathrm{~m}$. It was enlarged due to the strong wind that blows from it. It was presumed that some unknown large passages occur behind, but connection has not been proved. Temperature fluctuations that occur at Postojna 2 monitoring site are linked with air inflow from unknown cave areas (blow-holes or cave channels). Mixing of different air masses takes place at this location, especially in the winter time.

Mean annual temperature of air in the central part of the Lepe jame passage (Postojna 3 ) is $10.66^{\circ} \mathrm{C}$; it is for $0.5^{\circ} \mathrm{C}$ lower than at Velika gora (table 1). Temperature data show that temperature at Lepe jame (Postojna 3) has similar characteristics to temperature at Velika gora, regarding fluctuations. But seasonal trends are less significant at Lepe jame passage.

Also manually performed measurements of air temperature, which were collected at Postojna 1 and 2 (in years 2004-2010) were analyzed. These data exhibit slight increasing trend in temperature. This is in accordance with meteorological data for Postojna (figure 6).

Air temperature was measured at 10 minute intervals at two monitoring locations in Predjama cave system. These data from period $6^{\text {th }}$ August 2009 to $6^{\text {th }}$ August 2010 were analysed by basic statistics. Mean annual temperature of air in Konjski hlev passage is $8.67^{\circ} \mathrm{C}$ and $6.80^{\circ} \mathrm{C}$ in Velika dvorana chamber. Mean annual temperature of air in the forest above the Otoška jama cave was $9.25^{\circ} \mathrm{C}$ in the same period (table 3). Temperature in Konjski hlev exhibits the same seasonal trend as temperature at the surface (figure 7). Temperature influences of external air are relatively low in Velika dvorana in comparison with Konjski hlev. Air temperature fluctuates for $10.5^{\circ} \mathrm{C}$ in Velika dvorana in annual cycle, while fluctuations are $19^{\circ} \mathrm{C}$ in Konjski hlev (table 3). Temperature drops below freezing in Konjski hlev during winter. Air temperature in Velika dvorana is quite stable in summer time.

Vertical distance between monitoring site in Velika dvorana and Fiženca passage entrance (541 m a.s. 1.) is $49 \mathrm{~m}$ and horizontal distance is $35 \mathrm{~m}$. Vertical distance between the ponor of Lokva ( $460 \mathrm{~m}$ a. s. 1 .) and Fiženca is $81 \mathrm{~m}$. Air can easily enter the cave due to the distribution of great entrances at different altitudes. Also for this reason, the cave is very dynamic and air penetrates deep into the cave, at least to Vetrovna luknja.

\section{References}

Anelli, F. 1941-44: Osservazioni di meteorologia ipogea nelle Grotte di Castel Lueghi presso Postumia. Le Grotte d'Italia serie 2a-V. Postumia.

Badino, G. 2004: Cave temperatures and global climatic change. International Journal of Speleology 33-1/4. Trieste.

Badino, G. 2010: Underground meteorology - What's the weather underground?. Acta Carsologica 39-3. Ljubljana. 
Crestani, G., Anelli, F. 1939: Ricerche di meteorologia ipogea nelle grotte di Postumia. Publicazione 143. Roma.

Culver, D., Pipan, T. 2010: Climate, abiotic factors, and the evolution of subterranean life. Acta Carsologica 39-3. Ljubljana.

Gabrovšek, F., Mihevc, A. 2009: Cave climate. Postojna.

Gams, I. 1970: Zračna cirkulacija kot del jamskega okolja na primeru Postojnske jame. Skopje.

Gams, I. 2004: Kras v Sloveniji v prostoru in času, Založba ZRC. Ljubljana.

Habe, F. 1970: Predjamski podzemeljski svet. Acta Carsologica 5-1. Ljubljana.

Komac, B. 2009: Social memory and geographical memory of natural disasters. Acta geographica Slovenica 43-1. Ljubljana. DOI: 10.3986/AGS49107

Kranjc, A. 1983: Dinamika odpadanja sige v Golobji luknji, Predjama. Acta Carsologica 11. Ljubljana.

Lojen, S., Domínguez-Villar, D. 2010: Dinamika podzemne vode in okoljske spremembe v Postojnski jami: primer Pisanega rova. Ljubljana.

Smithson, P. A. 1991: Inter-Relationships Between Cave and Outside Air Temperatures. Theoretical and Applied Climatolology. 44. Hamburg.

Šebela, S. 2010: Accesses from the surface to the Postojna cave system. Annales, Series historia naturalis. 20. Koper.

Šebela, S., Turk, J. 2011: Local characteristics of Postojna Cave climate, air temperature, and pressure monitoring. Theoretical and Applied Climatology. 105. Hamburg. DOI: 10.1007/s00704-011-0397-9

Internet 1: http://www.arso.gov.si/vreme/napovedi\%20in\%20podatki/postojna.html (15.7.2010) 


\section{Značilnosti temperature zraka v Postojnskem in Predjamskem jamskem sistemu}

DOI: $10.3986 /$ AGS51102

UDK: 911.2:551.524(497.471)

551.524:551.435.84(497.471)

COBISS: 1.01

IZVLEČEK: Na petih mestih v dveh jamskih sistemih opravljamo zvezne meritve temperature zraka. Na Veliki gori (Postojna 1), ki je od treh merilnih mest v Postojnskem jamskem sistemu najvišje, smo v letih 2009 in 2010 zabeležili povprečno temperaturo $11,10^{\circ} \mathrm{C}$. V istem obdobju je bila ta temperatura $\mathrm{v}$ osrednjem rovu Lepih jam (Postojna 3) $10,66^{\circ} \mathrm{C}$ ter $10,30^{\circ} \mathrm{C}$ v stranskem rovu (Postojna 2). Največja temperaturna odstopanja $v$ primerjavi z zunanjostjo so na merilnem mestu Postojna 2 zaradi dotoka vetra iz neznanega ozadja predvsem v zimskem času. Večletno (2004 do 2010) ročno merjenje temperature zraka kaže na blago naraščanje na merilnih mestih Postojna 1 in 2 . V Predjamskem jamskem sistemu je temperatura v Veliki dvorani bolj stabilna kot v Konjskem hlevu, ki je zelo podvržen zunanjemu vplivu.

KLJUČNE BESEDE: geografija, krasoslovje, jamska klima, monitoring jamske klime, temperatura zraka, Postojnski jamski sistem, Predjamski jamski sistem, Slovenija

Uredništvo je prejelo prispevek 28. januarja 2011.

NASLOVA:

dr. Stanka Šebela

Inštitut za raziskovanje krasa

Znanstvenoraziskovalni center Slovenske akademije znanosti in umetnosti

Titov trg 2, SI - 6230 Postojna

E-pošta: sebela@zrc-sazu.si

\section{dr. Janez Turk}

Lunačkova 4, SI - 1000 Ljubljana, Slovenia

E-mail: janez.turk@zrc-sazu.si

\section{Vsebina}

1 Uvod 59

1.1 Opis merilnih mest $\quad 60$

$\begin{array}{lll}1.2 & \text { Metodologija } & 60\end{array}$

2 Rezultati in razprava 61

2.1 Postojnski jamski sistem 61

2.2 Predjamski jamski sistem 63

3 Sklep 64

4 Literatura 64 


\section{Uvod}

Postojnski (20.570 m) in Predjamski (13.092 m) jamski sistem sta med najdaljšimi in najbolj obiskanimi kraškimi jamami v Sloveniji. V okviru projektov Strokovni nadzor in svetovanje pri upravljanju z jamskimi sistemi, Klimatski in biološki monitoring jamskih sistemov (financer Postojnska jama d. d.) ter Meritve in analiza izbranih klimatskih parametrov v kraških jamah: primer sistema Postojnskih jam (sofinancer Javna agencija za raziskovalno dejavnost Republike Slovenije) izvajamo od 2009 redni monitoring jamske klime na izbranih lokacijah v dveh jamah. Zvezne meritve temperature zraka v Postojnskem jamskem sistemu (Postojna 2, slika 1) sicer opravljamo od 2008.

Slika 1: Postojnski in Predjamski jamski sistem z merilnimi točkami. 1 - Postojnski jamski sistem (1 - podzemeljska Pivka, 2 - merilna točka za temperaturo zraka), 2 - Predjamski jamski sistem (1 - merilna točka za temperaturo zraka, 1 =Konjski hlev, 2 =Velika dvorana). Glej angleški del prispevka.

V članku analiziramo osnovne statistične kazalnike temperature zraka v obeh jamskih sistemih za izbrano obdobje in podajamo osnovne značilnosti jamske klime na podlagi urnih oziroma deset minutnih meritev. $\mathrm{Na}$ primeru Postojnskega jamskega sistema prikazujemo tudi ročne meritve temperature zraka, ki smo jih naključno opravljali od leta 2004.

Postojnski jamski sistem predstavlja zapleten klimatski sistem zaradi velike dolžine rovov, velikih vhodov na različnih višinah, ponora reke Pivke ter velikih nihanj zunanje temperature in količine padavin med letom. Pozimi skozi večje vhode prodira v jamo mrzel zrak. Zrak se v jami segreje, postane lažji in se dviga proti površju skozi višje vhode ali številne razpoke. Poleti je kroženje zraka obrnjeno; hladnejši zrak izstopa iz Postojnskega jamskega sistema skozi spodnje vhode (Gabrovšek in Mihevc 2009).

Obsežno meteorološko študijo Postojnskega podzemlja sta opravila Crestani in Anelli (1939). Opravljala sta meritve temperature zraka, podzemeljske Pivke, kamnine ter smeri vetra, poleg tega pa še zračni pritisk in relativno vlago. Smeri gibanja zraka v hladnih in toplih obdobjih so prikazane na številnih prečnih prerezih, npr. Za Veliki dom, Otoško jamo, Pivko jamo. Študija zajema tudi vplive zmrzali v jami, predvsem $\mathrm{v}$ vhodnih delih ter meteorološke razmere dihalnikov na površju nad jamo.

Če se zrak, ki priteka od zunaj, v jami ohlaja, postaja težji in piha po jami navzdol, če se segreva, pa po jami navzgor. Takim jamam pravimo dinamične (Gams 2004). Intenzivnost mešanja jamskega zraka z zunanjim je odvisna od vrste dejavnikov, tudi od razmerja med velikostjo vhoda in globino jame ter gibanja zračnega pritiska. Ko pritisk raste, piha zrak v jamo, ob bližanju depresije pa iz nje. V vodnih jamah na gibanje vetra iz jame ali vanjo vplivata tudi dvig in upad vodne gladine (Gams 2004).

Postojnski jamski sistem sestavljajo klimatsko zelo različni deli. Dinamični z vidika kroženja zraka so predvsem Spodnji Tartar, Rov brez imena, Lepe jame, statična sta na primer rov Biospeleološke postaje in Pisani rov (Gams 1970).

Do prehoda v kroženju zraka iz enega v drug režim (značilnega za zimo ali poletje), prihaja včasih tudi med toplim opoldnevom in hladno nočjo. Spomladi in jeseni je kroženje zraka lahko zelo omejeno, ker so temperaturne razlike med jamo in zunanjim okoljem manjše. Seveda so izjeme. Ko so partizani spomladi leta 1944 razstrelili bencin v vhodnem rovu Postojnske jame, je veter pihal v jamo, tako je dim potemnil jamo do Kongresne dvorane (Gams 2004).

Tudi Predjamski jamski sistem je zaradi zapletene geometrije rovov in več vhodov na različnih viši nah zanimiv za študij jamske meteorologije. Anelli (1941-1944) je predstavil meteorološka opazovanja v Predjamskem jamskem sistemu z gibanjem zraka in merjenjem temperature. Opisuje princip zračne vre če, ki je značilen za Konjski hlev. Gre za dva zračna tokova različnih temperatur, ko eden vstopa in drugi zapušča jamo. Ob nizkih zimskih temperaturah, kot je bilo na primer januarja 1943, je iz Fižence izhajal topel jamski zrak, kar je v prvih jutranjih urah povzročilo oblak na vhodu v Fiženco (Anelli 1941-1944).

Habe (1970) je predstavil nekatere jamske temperaturne podatke od februarja 1956 do februarja 1957 za Lokvo, Staro jamo, Fiženco, Blatni rov, Veliko dvorano, Črno dvorano in Vzhodni rov v Predjamskem jamskem sistemu. Poleg tega je meril še veter, vlažnost in temperaturo kamnine. Habe (1970) je opisoval poletni in zimski režim ter vmesno dobo, ko prihaja do menjavanja zimske in letne smeri vetra. V poletnem zračnem gibanju teče zračni tok iz Zahodnega in Vzhodnega rova skozi Vetrovno luknjo do Velike dvorane, kjer se mu pridruži ohlajeni hladnejši zrak iz Fižence. Hladnejši jamski zrak tako uhaja iz vseh odprtin Lokve in Zmajeve luknje. Pozimi zračni tok vdira skozi Vetrovno luknjo v Črno dvorano. Največjo 
hitrost vetra v Vetrovni luknji so izmerili februarja leta 1956 in sicer 8,3 m/s. Ob nizkih zunanjih temperaturah segajo ledeni kapniki vse do Dvorane dvojčkov (Habe 1970).

Kranjc (1983) je opisal vpliv zmrzali na odlaganje sige v vhodnih delih Predjamskega jamskega sistema. Največ sige je odpadlo v pozni jeseni, najmanj pa poleti in zgodaj jeseni. V obdobju od 9.1.1980 do 31.3. 1981 je opravljal meritve temperature zraka in vlage v Golobji luknji in Vetrovni luknji. Največja izmerjena hitrost vetra v Vetrovni luknji je bila $9 \mathrm{~m} / \mathrm{s}$ (9.1.1981).

Vsak jamski sistem ima svojevrstne klimatske posebnosti, pri čemer veljajo splošne značilnosti mode lov jamske temperature (Smithson 1991), kar velja tudi za Postojnski in Predjamski jamski sitem. Sicer pa se raziskovanje jamske klime v zadnjih letih odvija zelo intenzivno (Badino 2010; Culver in Pipan 2010; Sebela in Turk 2011). Jamski prostori niso izvzeti niti iz podnebnih sprememb in naravnih nesreč (Badino 2004; Komac 2009).

\subsection{Opis merilnih mest}

$\mathrm{Z}$ ročnimi termometri smo odčitavali temperaturo zraka na dveh mestih, in sicer na merilnem mestu Postojna 1 od 26. 5. 2004 in na Postojna 2 od 18.5.2004. Merjenje smo kasneje nadgradili z natančnejšimi avtomatskimi inštrumenti. Temperaturo zraka smo najprej začeli meriti (21.7.2008) na merilnem mestu Postojna 2 v Lepih jamah (slika 1). Kasneje smo meritve razširili na merilni mesti Postojna 1 (18.3.2009) in Postojna 3 (6.5.2009). Merilno mesto Postojna 1 (Velika gora) je na nadmorski višini 561,4 m na vrhu podorne dvorane (slika 2), in sicer je $2 \mathrm{dm}$ nad tlemi in $1 \mathrm{dm}$ stran od podornega bloka. Nad dvorano je $65 \mathrm{~m}$ debel strop apnenca (Šebela 2010). Postojna 2 je v umetno povečanem stranskem rovu v Lepih jamah na nadmorski višini $526 \mathrm{~m}$ ter z $58 \mathrm{~m}$ debelim jamskim stropom. Inštrument je nameščen $3 \mathrm{dm}$ nad tle$\mathrm{mi}$ in $3 \mathrm{dm}$ stran od stene rova. Tretje merilno mesto (Postojna 3 ) je v sredini rova Lepih jam na nadmorski višini $524 \mathrm{~m}$ in je od merilnega mesta Postojna 2 oddaljeno okrog $12 \mathrm{~m}$ (slika 1). Inštrument je na mestu Postojna 3 od zasigane kamnine nameščen na razdalji $1 \mathrm{dm}$ in je $2 \mathrm{dm}$ dvignjen od tal.

Slika 2: Merjenje temperature zraka na Veliki gori (Postojna 1) (foto: Stanka Šebela 20.5.2009).

Glej angleški del prispevka.

Slika 3: Merjenje temperature zraka v Veliki dvorani (Predjamski jamski sistem) (foto: Stanka Šebela 12. 8. 2010) Glej angleški del prispevka.

Z meritvami temperature zraka v Predjamskem jamskem sistemu smo pričeli 6. 8. 2009. V jami smo vzpostavili dve merilni mesti. Prvo je v vhodnem delu, to je v Konjskem hlevu na nadmorski višini $488 \mathrm{~m}$, drugo pa v Veliki dvorani (492,5 m) (sliki 1 in 3). V Konjskem hlevu je inštrument $3 \mathrm{dm}$ dvignjen od tal ter $0,5 \mathrm{dm}$ oddaljen od stene rova. V Veliki dvorani pa je inštrument $0,5 \mathrm{dm}$ oddaljen od podornega blo ka in $3 \mathrm{dm}$ dvignjen od tal.

V Postojnskem jamskem sistemu so tri, v Predjamskem jamskem sistemu pa dve merilni mesti za temperaturo zraka. Poleg jamskih merilnih mest pa smo od 7. 10.2009 vzpostavili tudi merilno mesto izven jame, in sicer na površju v gozdu nad Otoško jamo na nadmorski višini 545 m (slika 1).

\subsection{Metodologija}

Temperaturo zraka smo merili z napravami imenovanimi diver-ji proizvajalca Van Essen. Temperaturna natančnost je $\pm 0.1^{\circ} \mathrm{C}$. Nekatera časovna obdobja v Postojnskem jamskem sistemu niso pokrita $\mathrm{z}$ meritvami zaradi različnih tehničnih težav pri organizaciji merjenja in odčitavanju podatkov. Meritve temperature zraka smo večinoma opravljali vsako uro, v nekaterih krajših obdobjih pa tudi v krajših inter valih npr. na 15 minut in 2 minuti.

V Predjamskem jamskem sistemu so potekale temperaturne meritve zvezno na obeh merilnih mestih; časovni interval med dvema meritvama je bil 10 minut.

Podatki o temperaturah zraka so predstavljeni z grafi (slike 4, 5, 6, 7 in 8 ). Hkrati so za primerjavo z jam skimi meritvami prikazani tudi podatki zunanje temperature, in sicer za Postojno (podatke smo pridobili na Agencije Republike Slovenije za okolje) ter za površje nad Otoško jamo. Glede na podobne reliefne in vegetacijske značilnosti, menimo, da se temperature zraka na površju pri Predjami in nad Otoško jamo 
bistveno ne razlikujejo, čeprav je razdalja med obema lokacijama okoli $9 \mathrm{~km}$. Zato smo zrak na površju merili samo nad Otoško jamo in te meritve uporabili tudi za primerjavo zunanjih in jamskih temperatur Predjame.

Zvezne podatke za obdobje enega leta (12.8.2009-12.8.2010 za Postojnski jamski sistem in 6. 8.2009-6. 8.2010 za Predjamski jamski sistem) smo obdelali tudi z osnovnimi statistikami, kjer smo za vsako merilno mesto podali najvišje, najnižje in srednje vrednosti temperature.

Podatki ročnega merjenja temperature zraka od leta 2004 (merilni mesti Postojna 1 in 2) so predstavljeni z grafom in temperaturnim trendom (slika 6) ter z osnovnimi statističnimi podatki. Podatki so bili odčitani najmanj enkrat mesečno.

\section{Rezultati in razprava}

\subsection{Postojnski jamski sistem}

Temperaturo zraka merjeno na treh mestih v Postojnskem jamskem sistemu smo statistično obdelali za eno letno obdobje (12.8.2009-12.8.2010), to je za zvezni niz podatkov na vseh treh lokacijah (preglednica 1).

Temperatura zraka je najvišja na merilnem mestu na Veliki gori (Postojna 1), kjer je povprečna let na temperatura $11,10^{\circ} \mathrm{C}$ (preglednica 1). Temperatura je tu razmeroma stabilna, v letnem ciklu niha zgolj za okoli $0,5^{\circ} \mathrm{C}$. Temperatura zraka na Veliki gori ima značilen sezonski temperaturni trend. Zrak v tem delu jame se jeseni in pozimi počasi ohlaja, spomladi in poleti pa lahko opazujemo počasno segrevanje. Zrak doseže svoj temperaturni višek približno konec septembra, medtem ko je temperaturni nižek konec marca (slika 4).

Preglednica 1: Osnovni statistični podatki merjenj temperature zraka za Postojnski jamski sistem (12. 8. 2009-12. 8. 2010).

\begin{tabular}{|c|c|c|c|c|}
\hline & $\begin{array}{c}\text { Postojna } 1- \\
\text { Velika gora }\left({ }^{\circ} \mathrm{C}\right)\end{array}$ & $\begin{array}{l}\text { Postojna } 2- \\
\text { Lepe jame }\left({ }^{\circ} \mathrm{C}\right)\end{array}$ & $\begin{array}{l}\text { Postojna } 3- \\
\text { Lepe jame }\left({ }^{\circ} \mathrm{C}\right)\end{array}$ & $\begin{array}{c}\text { Površje nad } \\
\text { Otoško jamo }\left({ }^{\circ} \mathrm{C}\right)\end{array}$ \\
\hline povprečje & 11,10 & 10,30 & 10,66 & 9,20 \\
\hline standardna deviacija & 0,12 & 0,27 & 0,09 & 8,74 \\
\hline število meritev & 8749 & 8752 & 8745 & 8754 \\
\hline najnižja vrednost & 10,89 & 9,89 & 10,34 & $-15,60$ \\
\hline najvišja vrednost & 11,37 & 10,99 & 11,23 & 32,10 \\
\hline
\end{tabular}

Slika 4: Temperature zraka v Postojnskem jamskem sistemu na treh točkah (Postojna 1, 2 in 3) in zunanja temperatura v stopinjah Celzija. Od 7.10.2009 so upoštevani podatki iz gozda nad Otoško jamo, do 7.10.2009 pa podatki za Postojno.

Glej angleški del prispevka.

Podoben sezonski trend letnih temperatur zraka opazujemo tudi na površju (podatki meritev nad Otoš ko jamo, slika 4). Vendar sta sezonski temperaturni višek in nižek na Veliki gori, v primerjavi s sezonskim viškom in nižkom na površju, zamaknjena. Najvišja povprečna mesečna temperatura zraka je v Postojni ponavadi dosežena julija (okoli $18^{\circ} \mathrm{C}$ ), le malo nižja je povprečna temperatura zraka v avgustu. Najbolj hladen mesec pa je januar (okoli $-1^{\circ} \mathrm{C}$ ) (december in februar sta običajno nekoliko manj mrzla). Sezonski temperaturni višek ali nižek v podzemlju (na Veliki gori) sta torej zamaknjena za približno dva do tri mesece $\mathrm{v}$ primerjavi s sezonskim viškom in nižkom na površju. Vendar je treba upoštevati, da so temperaturne spremembe $\mathrm{v}$ jamskem sistemu majhne v primerjavi z zunanjim okoljem. Temperatura zraka na Veliki gori se giblje okoli $11^{\circ} \mathrm{C}$, sezonski višek in nižek odstopata le za nekaj desetink stopinj Celzija. To pomeni, da se jama ohlaja v obdobju, ko je zunanja temperatura nižja od $11^{\circ} \mathrm{C}$ in segreva, ko je zunanja temperature višja od $11^{\circ} \mathrm{C}$. Šele ob koncu zime (druga polovica marca do aprila) se zunanja temperatura povzpne nad $11^{\circ} \mathrm{C}$ za daljše, to je večdnevno obdobje, s čimer prične tudi globoko v jamsko notranjost pritekati toplej ši zrak. Nasprotno velja ob pojavu sezonskega viška v jami. Konec septembra postanejo noči dovolj hladne (torej pod $11^{\circ} \mathrm{C}$ ) kar povzroči, da mrzel zrak v jamo vdira sprva vsaj ponoči (nato pa tudi podnevi). Posledično pride do obrata od segrevanja k počasnemu ohlajanja jamskega sistema (Šebela in Turk 2011).

Temperatura zraka na obeh drugih merilnih mestih v Postojnskem jamskem sistemu je izrazito nižja kot na Veliki gori (sliki 4 in 5). Merilno mesto na Veliki gori (Postojna 1) je na vrhu podorne dvorane, 
oziroma 35-37 m višje kot Lepe jame (Postojna 2 in 3). Ker je jama z vidika zračne dinamike zelo aktivna, je pod stropom, oziroma v vrhnjih delih velikih dvoran temperatura zraka stalno višja kot na dnu rovov in dvoran oziroma pri tleh.

Slika 5: Nihanje letnih temperatur zraka v stopinjah Celzija za Postojnski jamski sistem z označenimi kvartili in mediano (Postojna 1, 2 in 3). Glej angleški del prispevka.

Temperatura na merilnem mestu Postojna 2 se značilno razlikuje od tiste na Veliki gori (Postojna 1). Ne le da je izrazito nižja (slika 5), temveč ne kaže nobene značilne korelacije s temperaturo na Veliki gori (koeficient korelacije $r=-0,46$ ). Sezonski trend je tu ravno obraten kot bi pričakovali (slika 4). Temperatura je najnižja poleti, tedaj je tudi izredno stabilna, giblje se okoli $9,9-10,0^{\circ} \mathrm{C}$. Približno toliko znaša tudi minimalna temperatura zabeležena na Postojni $2\left(9,89^{\circ} \mathrm{C}\right)$ (preglednica 1$)$. V ostalih treh letnih časih, ko zunanje temperature (stalno ali pa vsaj ponoči) padejo pod jamsko temperaturo $10-11^{\circ} \mathrm{C}$, je tempe ratura zraka na merilnem mestu Postojna 2 zelo spremenljiva in v povprečju izrazito višja kot poleti. Celo minimalne zimske temperature so tu višje, kot so maksimalne poletne. Razmeroma velika temperaturna nihanja (nekaj desetink stopinj Celzija do okoli pol stopinje), ki se pojavljajo na Postojni $2 \mathrm{v}$ dnevnem ciklu (slika 4), so predvsem posledica spreminjanja smeri cirkulacije lokalnih zračnih mas v jami (Šebela in Turk 2011). Da prihaja največ zraka skozi dihalnike v stropu na zavoju Lepih jam, je opozoril že Gams (1970).

Povprečna letna temperatura zraka v Lepih jamah (Postojna 3) je po izmerjenih podatkih nižja od temperature zraka na Veliki gori skoraj za $0,5^{\circ} \mathrm{C}$ in je $10,66^{\circ} \mathrm{C}$ (preglednica 1 ). Iz temperaturnih podat kov je razvidno da kaže temperatura v Lepih jamah (Postojna 3 ) podobne zakonitosti kot na Veliki gori, le da so sezonski trendi manj izraziti. Na obeh lokacijah se pojavljajo podobna dnevna temperaturna nihanja (slika 4).

Temperaturni podatki ročnega merjenja na mestih Postojna 1 in 2 so predstavljeni na grafu (slika 6). Na obeh merilnih mestih smo v obdobju od 2004-2010 opazili blag trend naraščanja temperature zraka. Povprečna temperatura zraka za Postojna 1 (Velika gora) v obdobju od 26.5.2004 do 12.8.2010 je znašala $10,73^{\circ} \mathrm{C}$, za Lepe jame (Postojna 2) pa je v istem obdobju znašala $9,92^{\circ} \mathrm{C}$ (preglednica 2). Razlika v temperaturi zraka med Postojno 1 in 2 merjena z ročnimi termometri je $0,80^{\circ} \mathrm{C}$, razlika med Postojno 1 in 2 merjena $\mathrm{z}$ digitalnimi inštrumenti pa je $0,77^{\circ} \mathrm{C}$ (preglednica 2 ).

Tudi povprečna letna temperatura za Postojno (Internet 1) kaže v obdobju 2004-2009 rahlo naraščanje temperature.

Slika 6: Temperature zraka v stopinjah Celzija (2004-2010) v Postojnskem jamskem sistemu na dveh točkah (Postojna 1 in 2) in povprečna letna zunanja temperatura ob 7., 14. in 21. uri za meteorološko postajo Postojna (vir: ARSO). A - Postojna 1, B - Postojna 2, C - Postojna površje. Glej angleški del prispevka.

Jamska temperatura je običajno zelo povezana z zunanjim podnebjem. Svetovne klimatske spremembe lahko vplivajo tudi na podzemeljsko klimo (Badino 2004). Vendar pa so za večjo reprezentativnost te trditve potrebna merjenje in statistična obdelava dolgoletnih podatkov.

Modelni izračun prenosa toplote skozi kamnino v jamski prostor, je pokazal, da potuje temperatur ni signal s površja do Pisanega rova približno 20 let. Zato sklepajo, da temperatura stalno narašča in se bo predvidoma dvignila za stopinjo Celzija do leta 2030 (Lojen in Domínguez-Villar 2010). Glede na naše rezultate menimo, da je pri tem treba upoštevati tudi dotok toplote skozi glavne jamske vhode z naravno ventilacijo, kar se kaže tudi v dnevnih ciklih spreminjanja jamske temperature.

Preglednica 2: Osnovni statistični podatki merjenja temperature zraka $\left(v^{\circ} \mathrm{C}\right)$ za Postojnski jamski sistem (2004-2009).

\begin{tabular}{lccccc}
\hline & $\begin{array}{c}\text { povprečna T }\left({ }^{\circ} \mathrm{C}\right) \\
2004-2010\end{array}$ & $\begin{array}{c}\text { povprečna T }\left({ }^{\circ} \mathrm{C}\right) \\
\text { 2009-2010 }\end{array}$ & $\begin{array}{c}\text { T razlika } \\
\text { Postojna 1 in 2 } \\
(2004-2010)\end{array}$ & $\begin{array}{c}\text { T razlika } \\
\text { Postojna 1 in 2 } \\
(2009-2010)\end{array}$ & $\begin{array}{c}\text { Št. meritev } \\
\mathrm{N}\end{array}$ \\
\hline Postojna 1 & 10,73 & 11,09 & 0,81 & 0,77 & 115 \\
Postojna 2 & 9,92 & 10,32 & 0,81 & 0,77 & 118 \\
Postojna & $10,01^{*}$ & & & & 6576 \\
nad Otoško jamo & 9,2 & & & 8754 \\
\hline
\end{tabular}

*podatki za 2004-2009 (Internet 1) 


\subsection{Predjamski jamski sistem}

Meritve temperature zraka v Predjamskem jamskem sistemu smo opravili vsakih 10 minut, in sicer od 6. 8. 2009 do 6.8.2010. To obdobje je predstavljeno na sliki 7 ter v preglednici 3.

Povprečna letna temperatura zraka na merilnem mestu v Konjskem hlevu znaša $8,67^{\circ} \mathrm{C}$. V istem primerjalnem obdobju je bila povprečna letna temperatura zraka v gozdu nad Otoško jamo pri Postojni $9,25^{\circ} \mathrm{C}$ (preglednica 3). Izmerjena povprečna temperatura $\mathrm{v}$ Konjskem hlevu pa je zelo podobna dolgoletni povprečni temperaturi Postojne (1960-1990), ki znaša $8,4^{\circ} \mathrm{C}$ (internet 1 ). Zanimiva je razmeroma nizka povprečna letna temperatura zraka v Veliki dvorani, ki znaša zgolj $6,80^{\circ} \mathrm{C}$, kar je celo za $2,45^{\circ} \mathrm{C}$ manj od temperature nad Otoško jamo (preglednica 3 ).

Preglednica 3: Osnovni statistični podatki merjenja temperature zraka za Predjamski jamski sistem (6. 8.2009 do 6. 8. 2010).

\begin{tabular}{lccc}
\hline & Konjski hlev $\left({ }^{\circ} \mathrm{C}\right)^{*}$ & Velika dvorana $\left({ }^{\circ} \mathrm{C}\right)^{*}$ & Površje $\left({ }^{\circ} \mathrm{C}\right)^{* *}$ \\
\hline povprečje & 8,67 & 6,80 & 9,25 \\
standardna deviacija & 4,00 & 2,176 & 8,79 \\
število meritev & 52.399 & 52.424 & 8756 \\
najnižja vrednost & $-0,35$ & 0,81 & $-15,61$ \\
najvišja vrednost & 18,67 & 10,25 & 32,10 \\
\hline
\end{tabular}

* 10 minutni podatki

** urni podatki

Slika 7: Temperature zraka v Predjamskem jamskem sistemu na dveh točkah (Konjski hlev in Velika Dvorana) in zunanja temperatura iz gozda nad Otoško jamo v stopinjah Celzija.

Glej angleški del prispevka.

Temperaturna nihanja v Konjskem hlevu imajo enak trend kot temperaturna nihanja na površju. Meril no mesto v Konjskem hlevu je dovolj blizu vhoda, da ima površinski zrak zelo jasen in izrazit vpliv na jamsko temperaturo.

Podatki kažejo, da niha temperatura na merilnem mestu v Konjskem hlevu za več kot $18^{\circ} \mathrm{C}$ (v letnem ciklu). Glede na podatke za obdobje 6. 8.2009-6. 8.2010, se temperatura pozimi spusti za nekaj desetink stopinj Celzija pod ničlo, poleti pa naraste tudi do $18,67^{\circ} \mathrm{C}$ (preglednica 3 ). Tudi v dnevnem ciklu temperatura niha za skoraj $6^{\circ} \mathrm{C}$ (slika 7). Takšna velika dnevna temperaturna nihanja so značilna za toplejšo polovico leta, predvsem za poletje.

Habe (1970) je poročal, da v Konjskem hlevu nastaja lokalen zračni tok. Ta je sklenjen, del zraka se z 12 urno povratno dobo vrača in odhaja iz jame po istih jamskih rovih kot vanjo priteka. Takšen zračni tok lahko pojasnimo z vplivom zunanjih temperatur $\mathrm{v}$ Konjskem hlevu, kjer beležimo zelo jasna dnevna nihanja. Ta nastanejo zaradi temperaturnih razlik med dnevom in nočjo.

Drugo merilno mesto predstavlja Velika dvorana (slika 3) v kateri so zunanji vplivi manjši, kot v Konj skem hlevu. V Veliki dvorani so dnevna nihanja sicer še opazna, vendar je njihova amplituda neprimerno manjša kot na merilnem mestu v Konjskem hlevu (slika 7). Temperaturna nihanja zraka v Veliki dvorani v letnem ciklu znašajo skoraj $10,5^{\circ} \mathrm{C}, \mathrm{v}$ dnevnem ciklu pa temperatura niha za okoli $1{ }^{\circ} \mathrm{C}$ ali manj (preglednica 3).

Slika 8: Nihanje letnih temperatur zraka v stopinjah Celzija za Konjski hlev in Veliko dvorano v Predjamskem jamskem sistemu ter za površje (gozd nad Otoško jamo - 9 km stran od Predjame) z označenimi kvartili in mediano.

Glej angleški del prispevka.

Zanimivo je, da v toplejši polovici leta temperatura zraka v Veliki dvorani niha le $\mathrm{v}$ dnevnem ciklu. Nenadne spremembe v zunanjih temperaturnih trendih, pa se v Veliki dvorani ne odražajo, seveda v ko likor se ne spremeni smer kroženja zraka v jami. Temperatura zraka je bila v topli polovici merilnega obdobja približno $9,5^{\circ} \mathrm{C}$ (slika 8). Takoj spomladi, ko zunanje temperature narastejo in ne padajo več pod pov prečno letno temperaturo zraka na površju $\left(9-10^{\circ} \mathrm{C}\right)$, se prične zrak v Veliki dvorani počasi segrevati. Ta proces je postopen in traja do vrhunca poletja, ko se temperatura ustali na približno $9-10^{\circ} \mathrm{C}$. 


\section{Sklep}

Postojnski in predvsem Predjamski jamski sistem sta tipična sistema s številnimi vhodi, nanizanimi na različnih nadmorskih višinah. Oba predstavljata dinamičen in zapleten klimatski sistem, kjer segajo zunanji temperaturni vplivi daleč $\mathrm{v}$ notranjost. $\mathrm{V}$ obeh jamskih sistemih zasledimo zimski in poletni režim kroženja zraka.

Analiza urnih podatkov temperature zraka (12.8.2009-12.8.2010) na treh izbranih lokacijah v Postojnskem jamskem sistemu je pokazala zanimiva odstopanja, pa tudi podobnosti med njimi, predvsem $\mathrm{v}$ povezavi z zunanjo temperaturo. Med tremi merilnimi točkami je temperatura zraka najvišja na Veliki gori (Postojna 1), ki je od treh merilnih mest na najvišji nadmorski višini. Povprečna letna temperatura je tu $11,10^{\circ} \mathrm{C}$ (preglednica 1). V Lepih jamah (Postojna 2), kjer je merilna točka $35 \mathrm{~m}$ nižje od Velike gore, se temperatura zraka močno razlikuje od razmer na Veliki gori. Na lokaciji Postojna 2 je povprečna letna temperatura $10,30^{\circ} \mathrm{C}$, sezonski trend temperature zraka je tu obraten kot na Veliki gori, kjer je značilna sezonskost. Zrak na merilnem mestu $\mathrm{v}$ Veliki gori se jeseni in pozimi počasi ohlaja, spomladi in poleti pa lahko opazujemo počasno segrevanje (slika 4). Merilno mesto Postojna 2 je v umetno povečanem rovu manjše velikosti $(7 \times 1 \times 1,5 \mathrm{~m})$. Rov so zaradi močnega prepiha poskušali razširiti in povezati $\mathrm{z}$ neznanimi rovi, ki se domnevno nahajajo v ozadju. Temperaturna nihanja na merilnem mestu Postojna 2 so torej povezana $\mathrm{z}$ dotokom vetra iz neznanih jamskih predelov (bodisi dihalnikov ali jamskih rovov), ter $\mathrm{z}$ mešanjem različnih zračnih gmot, predvsem $\mathrm{v}$ zimskem času.

Povprečna letna temperatura zraka v osrednjem delu rova Lepih jam (Postojna 3 ) je nižja od tiste v Veliki gori skoraj za $0,5^{\circ} \mathrm{C}$ in je $10,66^{\circ} \mathrm{C}$ (preglednica 1 ). Iz temperaturnih podatkov je razvidno, da kaže temperatura v Lepih jamah (Postojna 3 ) podobne zakonitosti kot na Veliki gori, le da so sezonski trendi manj izraziti.

Analizirali smo tudi ročno odmerjene podatke temperature zraka za Postojno 1 in 2 (2004-2010), kjer se kaže manjši trend naraščanja temperature, kar je v skladu z meteorološkimi podatki za Postojno (sli ka 6).

Na dveh merilnih mestih v Predjamskem jamskem sistemu smo podatke temperature zraka merjene vsakih 10 minut analizirali z osnovnimi statističnimi metodami, in sicer za obdobje od 6.8.2009 do 6. 8.2010. Povprečna letna temperatura zraka v Konjskem hlevu je $8,67^{\circ} \mathrm{C}$, v Veliki dvorani pa le $6,80^{\circ} \mathrm{C}$. V istem obdobju je bila povprečna letna temperatura zraka v gozdu nad Otoško jamo pri Postojni $9,25^{\circ} \mathrm{C}$ (preglednica 3). Temperaturna nihanja v Konjskem hlevu imajo enak trend kot temperaturna nihanja na površju (slika 7). V Veliki dvorani so zunanji vplivi manjši kot v Konjskem hlevu. Temperaturno nihanje zraka je v Veliki dvorani v letnem ciklu skoraj $10,5^{\circ} \mathrm{C}$, medtem ko je ta podatek za Konjski hlev $19^{\circ} \mathrm{C}$ (preglednica 3). V Konjskem hlevu pozimi temperatura pade tudi pod $0^{\circ} \mathrm{C}$. Temperatura zraka je v poletnem obdobju v Veliki dvorani zelo stabilna.

Navpična razlika med merilnim mestom v Veliki dvorani in vhodom v Fiženco (541 m) je $49 \mathrm{~m}$, na vodoravni dolžini pa $35 \mathrm{~m}$. Med ponorom Lokve $(460 \mathrm{~m})$ in Fiženco pa je $81 \mathrm{~m}$ višinske razlike. Razpo reditev večjih vhodov na različnih višinah omogoča dober dostop zunanjega zraka in dinamičnost Predjamskega jamskega sistema globoko v notranjost, to je vsaj do Vetrovne luknje.

\section{Literatura}

Glej angleški del prispevka. 